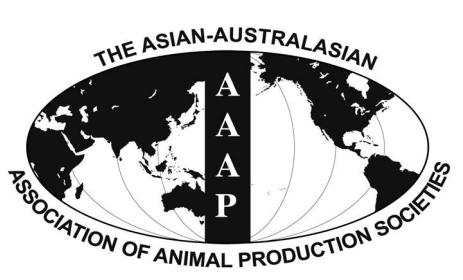

Open Access

\begin{tabular}{c} 
Open Access \\
Asian Australas. J. Anim. Sci. \\
Vol. 29, No. 8 : 1181-1187 August 2016 \\
http://dx.doi.org/10.5713/ajas.15.0659 \\
\hline www.ajas.info \\
pISSN 101 1-2367 elSSN 1976-5517
\end{tabular}

\title{
Carcass Traits and Meat Quality of Prestice Black-Pied Pig Breed
}

\author{
Václav Matoušek, Naděžda Kernerová*, Klára Hyšplerová, Dana Jirotková, and Michaela Brzáková \\ Faculty of Agriculture, University of South Bohemia in České Budějovice, České Budějovice 370 05, Czech Republic
}

\begin{abstract}
The objective of the study was to evaluate fattening performance, carcass value and meat quality in pigs of Prestice Black-Pied breed in relation to slaughter weight (SW) and gender (barrows and gilts, resp.). Pigs were divided into weight categories: SW1 (75 to $99.9 \mathrm{~kg})$, SW2 (100 to $109.9 \mathrm{~kg})$ and SW3 (110 to $130 \mathrm{~kg})$ and all individual traits were analyzed by the general linear model procedure (SAS 9.3). Average SW of each weight group was as follows: SW1 $94.2 \mathrm{~kg}$, SW2 $105.8 \mathrm{~kg}$, and SW3 $115.2 \mathrm{~kg}$. Differences among average backfat thickness of $36.07 \mathrm{~mm}$ in SW1, $40.16 \mathrm{~mm}$ in SW2, and $43.21 \mathrm{~mm}$ in SW3 were significant (p<0.01). Lean meat content was $48.94 \%$ (SW1), $48.78 \%$ (SW2), and 48.76\% (SW3). Pigs were slaughtered at average weight of $105.7 \mathrm{~kg}$ for barrows and $104.4 \mathrm{~kg}$ for gilts. Average backfat thickness for barrows was $40.90 \mathrm{~mm}$ and $38.72 \mathrm{~mm}$ for gilts (significant difference $\mathrm{p}<0.05$ ). Lean meat content was $48.75 \%$ in barrows and $48.91 \%$ in gilts. The values of $\mathrm{pH}_{45}$, characterizing the meat of very good quality. The loin in SW3 was darker than the muscles of SW1 and SW2. Drip loss was the lowest in SW1 (1.96\%), compared to the highest drip loss in SW3 (2.59\%). Content of intramuscular fat was 2.68\% in SW3, 2.79\% in SW2, and SW1 had the lowest content $2.47 \%$. The values of $\mathrm{pH}_{45}$, colour lightness and drip loss were similar in both genders. However barrows had higher intramuscular fat content by $0.31 \%$ than gilts $(\mathrm{p}<0.05)$. (Key Words: Pig, Native Breeds, Autochthonous Resources, Production Traits)
\end{abstract}

\section{INTRODUCTION}

The Prestice Black-Pied (PBP) pig is a Czech autochthonous breed from the western region of the Czech Republic. This breed is reared in a closed population which is included in the National Programme for Farm Animal Resources. The PBP breed, like other unimproved breeds, is characterized by a strong constitution and good maternity traits. The use of this local breed could produce specific and high-quality products with the regional label (Dostálová et al., 2012).

In pig breeding, selection has been successfully conducted to obtain leaner carcasses, higher growth rate, lower feed conversion and bigger litter size, based on a limited number of breeds (Rauw et al., 1998). The consequences of this strategy of selection are as follows: pig genetic diversity has been eroded and whole meat sensory characteristics and some reproductive and health traits have been undesirably affected. This is why the

\footnotetext{
* Corresponding Author: N. Kernerová. Tel: +42-0-38-777 2603, Fax: +42-0-38-531 0122, E-mail: kernerova@zf.jcu.cz

Submitted Aug. 8, 2015; Revised Oct. 14, 2015; Accepted Nov. 13, 2015
}

conservation of genetic resources has become a highpriority goal to support future livestock improvement (Alfonso et al., 2005). In many countries native pig breeds can provide suitable material for the good-quality products from pork that are more frequently demanded by consumers at present (Serrano et al., 2008). One possible way to improve pork quality is to put greater emphasis on native breeds of pigs (Bocian et al., 2012). Ruusunen et al. (2012) stated that the biggest differences in carcass and meat quality traits are usually found when comparing pigs of two genetically different pig breeds, i.e. traditional pig breeds which are not normally included in the commercial production of pork and western meat-producing breeds.

At present, farm animal genetic resources are used to a various extent and with different objectives in Slovakia (Oravcová et al., 2004). The use of highly productive breeds or hybrids aimed at profitable and competitive production prevails. To a smaller extent, breeds that are a part of Slovakia's and world cultural heritage are kept. The improvement of these breeds for high production or reproduction traits is not a priority. Among local breeds, Black-Pied breed was classified as endangered. According 
to Babicz et al. (2009) problems in the pork market associated with low prices that fail to compensate for production costs, have forced breeders to look for new solutions. One of these solutions is production of heavy fatteners as a material for maturing products. Pulawska breed can be used to produce fatteners with high body weight (135 to $140 \mathrm{~kg}$ ). Nurnberg et al. (2013) characterised the meat and fat quality of heavy female Saddleback pigs in comparison with conventional crossbreeds. The individual variations of carcass traits, meat quality and lipid profile of different tissues of heavy Saddleback pigs were very high. Because of the reduced growth performance this breed will be only a niche production line for pig breeding in Germany. The good meat quality, the high intramuscular fat content (IMF) $5.18 \%$ and the high backfat thickness guarantee perfect eating quality.

The objective of the study was to verify a hypothesis that no changes in carcass value occur in a small unselected population. The effect of slaughter weight (SW) and gender on the carcass value of pigs of PBP breed was studied on the basis of dressed carcass dissections and laboratory analyses of meat quality. The results were compared with carcass dissections performed more than 20 years ago before this population was included in the National Programme for Farm Animal Resources, and with the autochthonous breeds of similar genetic constitution in neighbouring countries.

The results of this study were compared with other indigenous breeds, on the ground of rearing indigenous breeds under altogether different conditions compared with modern breeds. Meat production from indigenous breeds is intended for the production of specific products.

\section{MATERIAL AND METHODS}

\section{Animals}

An experiment was conducted on 81 pigs of PBP breed (45 barrows and 36 gilts) in 6 fattening batches. The pigs were kept in normal housing conditions and received a standard feed mixture (ad libitum). Their fattening period started at an average age of 45 days. Based on SW, the pigs were divided into three weight categories, namely 75 to $99.9 \mathrm{~kg}$ (SW1), 100 to $109.9 \mathrm{~kg}$ (SW2), and 110 to $130 \mathrm{~kg}$ (SW3).

\section{Carcass measurements}

Left half-carcasses were dissected in accordance with the Methodology defined by Ministry of Agriculture of the Czech Republic. Backfat thickness was measured at three locations: in the middle of the 2nd thoracic vertebra, at the last thoracic vertebra and at the 1st lumbar vertebra (with skin). The arithmetic mean was calculated from these three measurements.
Lean meat content was determined by the ZP-Method (two-point method). The following equation was used for the calculation:

$$
\mathrm{Y}_{\mathrm{ZP}}=49.62542-0.63371 \mathrm{~B}_{\mathrm{ZP}}+0.23525 \mathrm{M}_{\mathrm{ZP}}
$$

$\mathrm{B}_{\mathrm{ZP}}$, backfat thickness with skin measured at the point of the lowest layer above the middle of musculus gluteus medius ( $\mathrm{mm})$.

$\mathrm{M}_{\mathrm{ZP}}$, muscle thickness between the cranial top of musculus gluteus medius and the dorsal edge of the spinal canal (mm).

A loin eye area was measured behind the last thoracic vertebra.

\section{Meat quality assessment}

A chop of $500 \mathrm{~g}$ of the longissimus lumborum et thoracis muscle (LM) was taken from the left side loin of each carcass at the last rib level.

$\mathrm{pH}$ values of the muscle were measured 45 minutes and 24 hours post mortem behind the last thoracic vertebra using a portable $\mathrm{pH}$-meter with puncture probe.

A ColorEye XTH spectrophotometer (calibrated to a white standard tile) was used to determine Commission Internationale de l'Eclairage (CIE) L* 24 hours post mortem. The chop was placed with fresh cut surface exposed to the air to allow the chop to be exposed to atmospheric oxygen for 30 minutes. An average of four random readings on the LM were used to measure lightness (higher $\mathrm{L}^{*}$ value is indicative of a lighter color).

Water-holding capacity of meat was determined by two methods as described by Honikel (1998).

Drip loss was determined as the weight loss of fresh meat sample $(150 \mathrm{~g})$ placed in a plastic bag after a storage time of 24 hours at $5^{\circ} \mathrm{C}$. Drip loss was expressed as a percentage of the initial weight.

A fresh sample about $50 \mathrm{~mm}$ thick from each chop was weight, placed in a thin-walled plastic bag and cooked in a water bath at a temperature of $70^{\circ} \mathrm{C}$ for 60 minutes. Samples were left to cool for 30 minutes. Cooking loss was determined as the difference of the sample weight before and after cooking the sample, divided by the initial weight.

Tenderness of raw and cooked meat was determined using a TA.XTPlus instrument fitted with a Warner-Bratzler shear blade (of $3 \mathrm{~mm}$ in thickness) at 24 hours post mortem as a shear force as described by Honikel (1998). The full scale load was set at $5 \mathrm{~kg}$ and the crosshead speed was 200 $\mathrm{mm} / \mathrm{min}$. Samples were cut parallel to the long axis of the muscle fibres into $10 \times 10 \mathrm{~mm}$ thick and $30 \mathrm{~mm}$ long slices. Shear force measurements were performed perpendicular to the fibre direction of at least eight subsamples.

Intramuscular fat content was determined by ether extraction in a Soxhlet apparatus for 2 hours and its content 
Table 1. Descriptive statistics of carcass traits

\begin{tabular}{lcccc}
\hline Trait & Mean & St. Dev. & Min. & Max. \\
\hline Slaughter weight $(\mathrm{kg})$ & 106.4 & 12.5 & 75.3 & 128.2 \\
Lifetime daily gain $(\mathrm{g})$ & 622 & 52 & 486 & 727 \\
Average backfat thickness $(\mathrm{mm})$ & 40.23 & 6.60 & 28.00 & 56.07 \\
Lean meat content $(\%)$ & 48.81 & 0.45 & 47.34 & 49.90 \\
Weight of ham $(\mathrm{kg})$ & 6.89 & 0.75 & 5.00 & 8.65 \\
Weight of loin $(\mathrm{kg})$ & 3.95 & 0.49 & 2.80 & 5.10 \\
Weight of shoulder $(\mathrm{kg})$ & 3.47 & 0.37 & 2.70 & 4.15 \\
Weight of neck $(\mathrm{kg})$ & 3.14 & 0.42 & 2.30 & 4.45 \\
Weight of belly $(\mathrm{kg})$ & 6.99 & 1.11 & 4.55 & 9.50 \\
Weight of meat cuts $(\mathrm{kg})$ & 17.42 & 1.88 & 12.45 & 21.15 \\
Percentage of meat cuts $(\%)$ & 39.68 & 2.90 & 33.20 & 47.59 \\
Percentage of ham $(\%)$ & 15.70 & 1.25 & 13.07 & 18.73 \\
Percentage of belly $(\%)$ & 15.92 & 1.21 & 13.66 & 19.47 \\
Loin eye area $\left(\mathrm{mm}^{2}\right)$ & 4,107 & 676 & 2,547 & 5,896 \\
\hline
\end{tabular}

was expressed in percentage.

\section{Statistical analysis}

Descriptive statistics of carcass traits and meat quality are shown in Table 1 and 2.

Fixed effects included in the evaluation were tested by the least-square method (GLM/SAS). The model equation was described as follows:

$$
\begin{aligned}
\mathrm{Y}_{\mathrm{ijklm}}= & \mu+\text { Group }_{\mathrm{i}}+\mathrm{SW}_{\mathrm{j}} \\
& + \text { Gender }_{\mathrm{k}}+\mathrm{Age}_{\mathrm{l}}+\mathrm{SW}^{*} \text { Gender }_{\mathrm{m}}+\mathrm{e}_{\mathrm{ijklm}}
\end{aligned}
$$

$\mathrm{Y}_{\mathrm{ijklm}}=$ observed trait,

$\mu=$ estimated mean value of a trait for the animals included in the model,

Group $_{\mathrm{i}}=$ fixed effect of group (fattening batches),
Table 2. Descriptive statistics of meat quality

\begin{tabular}{lcccc}
\hline Trait & Mean & St. Dev. & Min. & Max. \\
\hline $\mathrm{pH}_{45}$ & 6.66 & 0.23 & 5.97 & 7.09 \\
$\mathrm{pH}_{24}$ & 5.50 & 0.11 & 5.24 & 5.72 \\
Colour lightness (L*) & 52.98 & 2.23 & 48.22 & 59.00 \\
Drip loss (\%) & 2.31 & 0.97 & 1.31 & 4.65 \\
Cooking loss (\%) & 27.65 & 6.03 & 14.30 & 37.51 \\
Intramuscular fat (\%) & 2.67 & 0.73 & 1.28 & 4.80 \\
Shear force - raw meat (kg) & 1.51 & 0.42 & 0.93 & 2.54 \\
Shear force - cooked meat (kg) & 7.64 & 1.81 & 3.00 & 11.89 \\
\hline
\end{tabular}

$\mathrm{SW}_{\mathrm{j}}=$ fixed effect of slaughter weight category,

Gender $_{\mathrm{k}}=$ fixed effect of gender,

$\mathrm{Age}_{1}=$ fixed effect of age at slaughter,

$\mathrm{SW}^{*}$ Gender $_{\mathrm{m}}=$ interaction of slaughter weight * gender, $\mathrm{e}_{\mathrm{ijklm}}=$ random error.

\section{RESULTS AND DISCUSSION}

\section{Carcass value}

The values of statistical analysis aimed at the effect of slaughter weight on production traits are documented in Table 3. There were significant differences $(p<0.01)$ in fattening performance and carcass traits between the weight categories. Average slaughter weight was found to be 94.2 $\mathrm{kg}$ in SW1, in SW2 it was $105.8 \mathrm{~kg}$ and in SW3 was 115.2 $\mathrm{kg}(\mathrm{p}<0.001)$. The lowest lifetime daily gain was $557 \mathrm{~g}$ in $\mathrm{SW} 1$, higher gain by about $70 \mathrm{~g}$ was in SW2 (627 g) and the highest one was in SW3 $(661 \mathrm{~g})(\mathrm{p}<0.001)$. In a progeny test (from 30 to $100 \mathrm{~kg}$ ) Kolář and Pavlík (1989) confirmed the average daily gain of $753 \mathrm{~g}$ and Klusáček et al. (1991) reported the weight gain of 788.42 g. Improved pigs of PBP breed (75\% PBP, 25\% Landrace) reached

Table 3. The effect of slaughter weight and gender on fattening performance and carcass traits

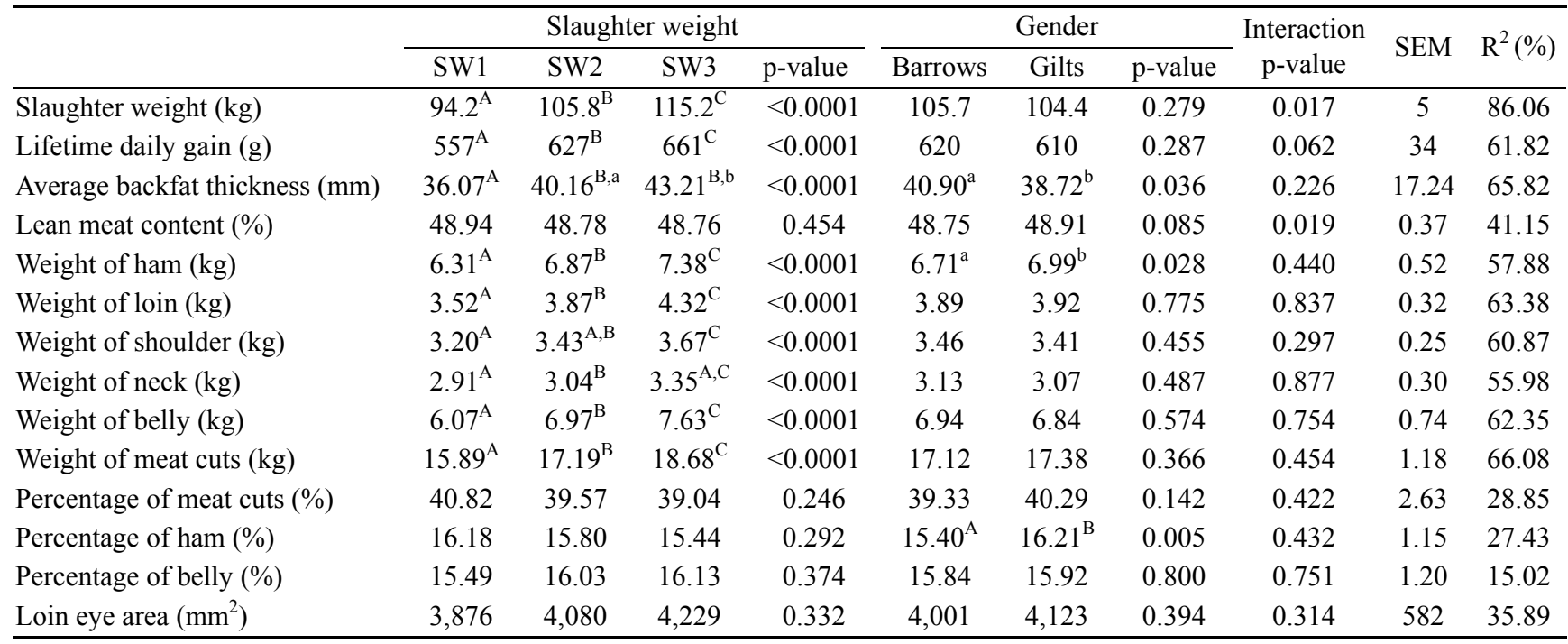

SW, slaughter weight (SW1: 75 to $99.9 \mathrm{~kg}, \mathrm{SW}$ : 100 to $109.9 \mathrm{~kg}$, SW3: 110 to $130 \mathrm{~kg}$ ); SEM, standard error of the mean.

${ }^{a, b}$ Least square means (LSM) in rows with different letters differ significantly at $\mathrm{p}<0.05$.

${ }^{\mathrm{A}, \mathrm{B}, \mathrm{C}}$ Least square means (LSM) in rows with different letters differ significantly at $\mathrm{p}<0.01$. 
higher daily gain. In PBP pigs fattened in a conventional feeding system Dostálová et al. (2012) reported average daily gain of $650 \mathrm{~g}$ at slaughter weight of $92 \mathrm{~kg}$ (186 days). Szulc et al. (2012) recorded a markedly lower average daily gain in Zlotnicka spotted breed.

Backfat thickness can be considered as the basic parameter of carcass fatness. In the studied population backfat thickness was correlated with carcass weight. The lowest average backfat thickness was measured at 36.07 $\mathrm{mm}$ in SW1, the highest of $43.21 \mathrm{~mm}$ in SW3 group. SW1 group was different $(\mathrm{p}<0.001)$ from SW2 and SW3 groups while SW2 group was significantly different from SW3 group.

In traditional breeds the values of backfat thickness are in general much higher than those obtained from modern breeds that are selected for leaner carcasses. In a progeny test (30 to $100 \mathrm{~kg}$ ) Kolář and Pavlík (1989) and Klusáček et al. (1991) reported in PBP breed lower average backfat thickness. Lower average backfat thickness was recorded in Zlotnicka Spotted breed by Kapelanski et al. (2006) and by Szulc et al. (2012) too. Szulc et al. (2011) recorded in Zlotnicka Spotted breed high average backfat thickness. Candek-Potokar et al. (2003) reported backfat thickness of $29 \mathrm{~mm}$ (at carcass weight of $98 \mathrm{~kg}$ ) in the Slovene local pig breed Krškopolje.

For objective evaluation of pig carcasses or for their marketing it is necessary to measure the lean meat percentage. Native breeds are not selected for utility traits; therefore they do not reach the same lean meat content as breeds selected for meatiness. In the studied population lean meat content decreased in the particular weight categories: $48.94 \%, 48.78 \%$, and $48.76 \%$. Differences between weight categories were very small, and they were not significant ( $p$ $=0.454$ ). In older literature sources Pulkrábek et al. (1993) stated that in a progeny test PBP breed had the lowest lean meat content among maternal breeds. Compared to the studied population, lower values of lean meat content were measured in Polish original breeds. In Zlotnicka Spotted breed Szulc et al. (2011) recorded the value of 43.99\% (114 $\mathrm{kg})$ and Szulc et al. (2012) measured 41.83\% (119.20 kg). Also Candek-Potokar et al. (2003) reported in Krškopolje breed lower lean meat content. Final weight of 90.7, 89.7, and $87.1 \mathrm{~kg}$ and lean meat content of 57.4, 54.1, and 55.1\% were determined in Duroc-sired progeny from three maternal breed types Camborough 12, Saddleback and Saddleback $\times$ Duroc (Kelly et al., 2007).

The weight of meat cuts (ham, loin, shoulder, neck), as well as of belly was gradually increasing. The weight of meat cuts increased from $15.89 \mathrm{~kg}$ in the lowest weight category through $17.19 \mathrm{~kg}$ in SW2 to $18.68 \mathrm{~kg}$ in the heaviest weight category $(p<0.01)$. Similar results were found in the weight of belly. The highest percentage of meat cuts $(40.82 \%)$ measured in SW1 group followed by SW2 group (39.57\%) and the lowest percentage of meat cuts was found out in SW3 (39.04\%). A difference between SW1 and SW3 groups was $1.78 \%$. This situation was also observed in ham percentage. A difference between SW1 (16.18\%) and SW3 (15.44\%) groups was $0.74 \%$. Belly percentage increased from $15.49 \%$ (SW1 group) to $16.03 \%$ and $16.13 \%$ (SW2 and SW3 group, respectively). In older literature, Kolár and Pavlík (1989) reported that in a progeny test of pigs of PBP breed the percentage of meat cuts was $46.01 \%$ and ham percentage amounted to $17.82 \%$; the values of Klusáček et al. (1991) were $47.24 \%$ and $18.8 \%$ for the percentage of meat cuts and ham, resp. It is to note that the percentage of meat cuts was higher than in the studied population. Dostálová et al. (2012) determined in PBP pigs a markedly higher percentage of meat cuts while Kapelanski et al. (2006) found the value of $44.69 \%$ for the percentage of meat cuts in Zlotnicka Spotted breed (97.31 $\mathrm{kg}$ ).

Loin eye area increased with increasing slaughter weight. The measured values for the particular groups were $3,876,4,080$, and $4,229 \mathrm{~mm}^{2}$. A larger increase in loin eye area was observed in SW2 group (about $204 \mathrm{~mm}^{2}$ ) while an increase in SW3 group was smaller (about $149 \mathrm{~mm}^{2}$ ). A similar value of loin eye area in PBP pigs was reported by Kolář and Pavlík (1989) and by Klusáček et al. (1991). Lower values were also reported in Polish native breeds (Kapelanski et al., 2006; Jankowiak et al., 2009; Szulc et al., 2011; Bocian et al., 2012). Candek-Potokar et al. (2003) reported the value of $4,170 \mathrm{~mm}^{2}(98 \mathrm{~kg})$ for loin eye area in Krškopolje breed.

Table 3 shows statistical characteristics of fattening traits and carcass dissection according to gender. The animals of both genders were slaughtered at similar slaughter weight (105.7 kg in barrows and $104.4 \mathrm{~kg}$ in gilts). Barrows had higher average lifetime daily gain $(620 \mathrm{~g})$ compared to gilts $(610 \mathrm{~g})$. In Zlotnicka Spotted breed Szulc et al. (2012) recorded daily gain in barrows of $570 \mathrm{~g}$ $(116.60 \mathrm{~kg})$ and in gilts $610 \mathrm{~g}(121.80 \mathrm{~kg})$. Basque BlackPied and Large White barrows were slaughtered at 202 days of age (Alfonso et al., 2005). Their weight was 86.2 and $126.6 \mathrm{~kg}$ and average daily gain was 488 and $763 \mathrm{~g}$.

A difference of $2.19 \mathrm{~mm}(\mathrm{p}<0.05)$ only was determined in average backfat thickness in barrows $(40.90 \mathrm{~mm})$ and gilts $(38.72 \mathrm{~mm}$ ). Kapelanski et al. (2006) reported in Zlotnicka Spotted breed average backfat thickness adjusted to $100 \mathrm{~kg}$ weight to be $33.2 \mathrm{~mm}$ in barrows and $31.7 \mathrm{~mm}$ in gilts. Baulain et al. (2000) measured backfat thickness of 30.6 to $31.4 \mathrm{~mm}$ in barrows of the breeds Angeln Saddleback, Bentheimer Black-Pied and Swabian Hall Saddleback. In Angeln Saddleback and Bentheimer BlackPied gilts backfat thickness was 31.1 and $28.6 \mathrm{~mm}$ at the weight of 84.1 and $85 \mathrm{~kg}$, resp. Alfonso et al. (2005) compared Basque Black-Pied and Large White barrows 
when Basque Black-Pied barrows had higher backfat thickness at point $\mathrm{B}$.

Lean meat content in barrows and in gilts was $48.75 \%$ and $48.91 \%$, respectively. Most authors have confirmed higher lean meat content in gilts. E.g. Szulc et al. (2012) found that in Zlotnicka Spotted breed the lean meat content was $39.02 \%$ in barrows $(116.6 \mathrm{~kg})$ and $44.64 \%$ in gilts $(121.8 \mathrm{~kg})$, confirming higher lean meat content in gilts. Baulain et al. (2000) reported in Angeln Saddleback, Bentheimer Black-Pied and Swabian Hall Saddleback breeds the lean meat content of $46.3 \%$ to $48.2 \%$ in barrows $(82.5$ to $84.1 \mathrm{~kg})$ while the values for Angeln Saddleback and Bentheimer Black-Pied gilts were $48.2 \%$ and $50.3 \%$ $(84.1$ and $85.0 \mathrm{~kg})$.

Gilts were found to have higher weight of ham $(\mathrm{p}<0.05)$ and loin whereas barrows had higher weight of shoulder and neck. But differences were very small. No large difference was determined between genders in the percentage of meat cuts $(39.33 \%$ in barrows, $40.29 \%$ in gilts), but difference in the percentage of ham was highly significant $(\mathrm{p}<0.01)$. Kapelanski et al. (2006) confirmed in Zlotnicka Spotted breed a higher percentage of meat cuts in gilts, $45.63 \%$ than in barrows, $43.57 \%$. The Celta is a unique indigenous pig breed of Galicia (north-western Spain) (Franco and Lorenzo, 2013). In this breed, the percentage of parts representing meat cuts was higher in barrows than in gilts in relation to slaughter weight.

An insignificantly larger loin eye area was measured in gilts $\left(4,123 \mathrm{~mm}^{2}\right)$ compared to barrows $\left(4,001 \mathrm{~mm}^{2}\right)$. Kapelanski et al. (2006) reported in Zlotnicka Spotted breed a smaller loin eye area calculated per $100 \mathrm{~kg}$ in barrows and in gilts.

\section{Meat quality traits}

Table 4 shows statistical characteristics of meat quality according to slaughter weight. The values ranging from 6.65 to 6.68 were determined in the particular weight categories for $\mathrm{pH}$ measured at 45 minutes. The average values were at the level describing normal meat. Most authors found lower values in native breeds than the $\mathrm{pH}_{45}$ values measured in the studied population. Szulc et al. (2012) measured $\mathrm{pH}_{45} 6.15$ in Zlotnicka Spotted breed. In Krškopolje breed Candek-Potokar et al. (2003) reported the relatively low $\mathrm{pH}_{1}$ value of 5.84. Baulain et al. (2000) described $\mathrm{pH}_{45}$ values of $6.18,6.16$, and 6.25 in pig breeds Angeln Saddleback, Bentheimer Black-Pied and Swabian Hall Saddleback. The meat of pigs of Basque Black-Pied breed had higher $\mathrm{pH}_{2 \mathrm{H}}$ than the meat of Large White breed (Alfonso et al., 2005).

The values of $\mathrm{pH}$ measured at 24 hours ranged from 5.48 to 5.53. Grzeskowiak et al. (2009) measured the $\mathrm{pH}_{24}$ values of 5.53 and 5.56 in Zlotnicka White and Zlotnicka Spotted breed, respectively. Higher values than in the studied population were published by Candek-Potokar et al. (2003) in Krškopolje breed.

The $m$. longissimus lumborum et thoracis from SW3 group was darker (lower $\mathrm{L}^{*}$ ) than the muscles from SW1 and SW2 groups (no significant difference). Other authors mostly reported lower values in native breeds (Bocian et al., 2012; Szulc et al., 2012). Alfonso et al. (2005) demonstrated that the meat of Basque Black-Pied breed was darker than the meat of Large White pigs. A higher value than that determined in the studied population was reported by Candek-Potokar et al. (2003) in Krškopolje breed.

Water-holding capacity, expressed as drip loss, was found to be the lowest in SW1 weight category $1.96 \%$, intermediate in SW2 category $2.26 \%$ and the highest in SW3 weight category $2.59 \%$. With increasing slaughter weight the values of cooking loss were found to decrease from $29.54 \%$ in SW1 weight category to $26.44 \%$ in SW3 weight category. Water-holding capacity is an important trait associated with pH value. Grzeskowiak et al. (2009) compared Zlotnicka White and Zlotnicka Spotted breeds and measured the drip loss value higher than in the studied population. Bocian et al. (2012) demonstrated lower drip loss in Zlotnicka Spotted breed than in hybrids of Polish

Table 4. The effect of slaughter weight and gender on meat quality

\begin{tabular}{|c|c|c|c|c|c|c|c|c|c|c|}
\hline & \multicolumn{4}{|c|}{ Slaughter weight } & \multicolumn{3}{|c|}{ Gender } & \multirow{2}{*}{$\begin{array}{c}\text { Interaction } \\
\text { p-value }\end{array}$} & \multirow{2}{*}{ SEM } & \multirow{2}{*}{$\mathrm{R}^{2}(\%)$} \\
\hline & SW1 & SW2 & SW3 & $\mathrm{p}$-value & Barrows & Gilts & $\mathrm{p}$-value & & & \\
\hline$\overline{\mathrm{pH}_{45}}$ & 6.68 & 6.65 & 6.66 & 0.920 & 6.63 & 6.70 & 0.225 & 0.118 & 0.23 & 12.84 \\
\hline $\mathrm{pH}_{24}$ & 5.50 & 5.48 & 5.53 & 0.233 & 5.51 & 5.50 & 0.767 & 0.070 & 0.08 & 48.93 \\
\hline Colour lightness $\left(\mathrm{L}^{*}\right)$ & 53.31 & 53.30 & 52.32 & 0.338 & 53.03 & 52.92 & 0.849 & 0.426 & 2.21 & 15.36 \\
\hline Drip loss (\%) & 1.96 & 2.26 & 2.59 & 0.175 & 2.36 & 2.19 & 0.420 & 0.392 & 0.83 & 36.51 \\
\hline Cooking loss (\%) & 29.54 & 27.49 & 26.44 & 0.189 & 27.99 & 27.65 & 0.744 & 0.535 & 4.16 & 58.98 \\
\hline Intramuscular fat (\%) & 2.47 & 2.79 & 2.68 & 0.388 & $2.80^{\mathrm{a}}$ & $2.49^{\mathrm{b}}$ & 0.054 & 0.038 & 0.64 & 33.29 \\
\hline Shear force - raw meat $(\mathrm{kg})$ & $1.72^{\mathrm{A}, \mathrm{a}}$ & $1.47^{\mathrm{B}, \mathrm{b}}$ & $1.37^{\mathrm{B}}$ & 0.023 & 1.52 & 1.53 & 0.918 & 0.390 & 0.31 & 50.75 \\
\hline Shear force - cooked meat $(\mathrm{kg})$ & $8.71^{\mathrm{a}}$ & $7.15^{\mathrm{b}}$ & $7.07^{\mathrm{b}, \mathrm{c}}$ & 0.028 & 7.72 & 7.58 & 0.736 & 0.216 & 1.69 & 25.00 \\
\hline
\end{tabular}

SW, slaughter weight (SW1: 75 to $99.9 \mathrm{~kg}$, SW2: 100 to $109.9 \mathrm{~kg}$, SW3: 110 to $130 \mathrm{~kg}$ ); SEM, standard error of the mean.

${ }_{\mathrm{a}, \mathrm{b}, \mathrm{c}}$ Least square means (LSM) in rows with different letters differ significantly at $\mathrm{p}<0.05$.

${ }^{\mathrm{A}, \mathrm{B}}$ Least square means (LSM) in rows with different letters differ significantly at $\mathrm{p}<0.01$. 
Large White $\times$ Polish Landrace breeds.

IMF content influences eating quality, i.e. tastiness, juiciness and tenderness of meat. Krieter and Tholen (2001) considered $2.5 \%$ as optimum IMF content. The data of Fernandez et al. (1999) suggested that the acceptability of pork may be improved by increasing the IMF content. But this effect disappeared for IMF content higher than 3.5\%, which is associated with a high risk of meat rejection due to visible fat. It is generally accepted that traditional breeds produce a higher IMF content. In the studied population IMF content in loin was $2.68 \%$ and $2.79 \%$ in SW3 and SW2 group, respectively, while in SW1 group it was the lowest, i.e. $2.47 \%$. Lower IMF content than in the studied population was reported Grzeskowiak et al. (2009) in Zlotnicka White breed and in Zlotnicka Spotted breed. Higher IMF content of 3\% was reported by Candek-Potokar et al. (2003) in Krškopolje breed. Alfonso et al. (2005) compared the pig breeds Basque Black-Pied and Large White. The meat of Basque Black-Pied breed showed a greater degree of marbling.

Meat became tenderer with higher slaughter weight in both, as indicated by the shear force of raw and cooked meat. SW1 group was significantly different $(p<0.05)$ from SW2 and SW3 groups in shear force of raw meat, SW1 group was highly significantly different $(p<0.01)$ from SW3 group. Jankowiak et al. (2010) did not report any difference in meat tenderness between Zlotnicka Spotted pigs and Polish Large White $\times$ Polish Landrace hybrids.

Table 4 documents the results of meat quality evaluation in relation to gender. The values of $\mathrm{pH}$, particularly $\mathrm{pH}_{24}$, were similar in barrows and gilts. Similar values in barrows and gilts were also confirmed by some authors. In Zlotnicka Spotted breed Kapelanski et al. (2006) reported for barrows and gilts $\mathrm{pH}_{45}$ values of 6.54 and 6.51 and $\mathrm{pH}_{24}$ values of 5.43 and 5.45, respectively. Some authors reported different values of $\mathrm{pH}_{45}$. Szulc et al. (2012) recorded the $\mathrm{pH}_{45}$ values of 6.24 and 6.06 in barrows and gilts of Zlotnicka Spotted breed. Also in Celta breed the gender significantly influenced $\mathrm{pH}_{45}$ (6.37 and 6.72) in barrows and gilts (Franco and Lorenzo, 2013).

The values of colour lightness $\left(\mathrm{L}^{*}\right)$ were also very similar in barrows and gilts. Szulc et al. (2012) recorded in Zlotnicka Spotted breed L* 51.83 in barrows and L* 49.09 in gilts. In Celta breed the gender had a highly significant influence on colour lightness (Franco and Lorenzo, 2013).

No significant differences were found out in the studied population between barrows and gilts in water-holding capacity, i.e. in drip loss and cooking loss.

IMF content was higher by $0.31 \%(\mathrm{p}<0.05)$ in barrows $(2.80 \%)$ than in gilts $(2.49 \%)$. Baulain et al. (2000) confirmed different values of IMF content between genders. In barrows of the breeds Angeln Saddleback, Bentheimer
Black-Pied and Swabian Hall Saddleback IMF contents were $1.36 \%$ to $1.64 \%$ while in Angeln Saddleback and Bentheimer Black-Pied gilts the values of IMF content were $0.95 \%$ and $1.05 \%$. Franco and Lorenzo (2013) did not find a significant difference in IMF content between genders of Celta breed. In barrows IMF content amounted to $2.12 \%$ $(143.2 \mathrm{~kg})$ and in gilts to $1.67 \%(134.6 \mathrm{~kg})$.

In the studied population the gender did not influence either the values of shear force-raw meat or the values of shear force-cooked meat. Neither did Franco and Lorenzo (2013) find a significant difference in Celta breed between barrows and gilts in shear force. Nurnberg et al. (1997) compared German Saddleback and German Landrace barrows and no significant difference was found between the breeds.

\section{CONCLUSION}

Lower growth ability, early and higher adipose tissue development and lower carcass value were characteristic of PBP breed during fattening in standard rearing conditions. These findings are typical of native breeds of pigs. With increasing slaughter weight the average backfat thickness, weight of meat cuts and belly and loin eye area increased, while lean meat content decreased. Meat quality received a very positive evaluation. The meat of the heaviest weight category was darker, with the highest IMF content. The recommended value of IMF content $(2.5 \%)$ was reached in all studied categories $(2.47 \%$ to $2.79 \%)$. It can be assumed that the meat with higher proportion of IMF will be tenderer, juicier, with typical smell and taste of pork. The results showed that slaughter weight was a significant factor for carcass traits and an insignificant factor for most parameters of meat quality. The higher fat content of carcasses of PBP pigs can be used for the production of specific meat products.

\section{CONFLICT OF INTEREST}

We certify that there is no conflict of interest with any financial organization regarding the material discussed in the manuscript.

\section{ACKNOWLEDGMENTS}

This study was supported by Projects QJ 1210253, QI 111B107, and GAJU 020/2013/Z.

\section{REFERENCES}

Alfonso, L., J. Mourot, K. Insausti, J. A. Mendizabal, and A. Arana. 2005. Comparative description of growth, fat deposition, 
carcass and meat quality characteristics of Basque and Large White pigs. Anim. Res. 54:33-42.

Babicz, M., P. Kamyk, A. Stasiak, and M. Pastwa. 2009. Opportunities to use Pulawska pigs for heavy fattener production. An. Anim. Sci. 9:259-268.

Baulain, U., P. Kohler, E. Kallweit, and W. Brade. 2000. Intramuscular fat content in some native German pig breeds. Quality of Meat and Fat in Pigs as Affected by Genetics and Nutrition. Proceedings of the Joint Session of the EAAP Commissions on Pig Production, Animal Genetics and Animal Nutrition, Zurich, Switzerland, August 25, 1999. 100:181-184.

Bocian, M., D. Wojtysiak, H. Jankowiak, A. Cebulska, W. Kapelanski, and W. Migdal. 2012. Carcass, meat quality and histochemical traits of $\mathrm{m}$. longissimus lumborum from Zlotnicka Spotted pigs and commercial pigs. Folia Biol. (Krakow). 60:181-187.

Candek-Potokar, M., B. Zlender, Z. Kramar, B. Segula, G Fazarinc, and M. Ursic. 2003. Evaluation of Slovene local pig breed Krskopolje for carcass and meat quality. Czech J. Anim. Sci. 48:120-128.

Dostálová, A., M. Koucký, L. Vališ, and M. Šimečková. 2012. Evaluation of fattening performance, carcass traits and meat characteristics of Prestice Black-Pied pigs in the organic freerange and conventional system. Res. Pig Breed. 6:15-19.

Fernandez, X., G. Monim, A. Talmant, J. Mourot, and B. Lebret. 1999. Influence of intramuscular fat content on the quality of pig meat -2 . Consumer acceptability of $\mathrm{m}$. longissimus lumborum. Meat Sci. 53:67-72.

Franco, D. and J. M. Lorenzo. 2013. Effect of gender barrows vs. females on carcass traits and meat quality of Celta pig reared outdoors. J. Sci. Food Agric. 93:727-734

Grzeskowiak, E., A. Borys, K. Borzuta, J. T. Buczynski, and D. Lisiak. 2009. Slaughter value, meat quality and backfat fatty acid profile in Zlotnicka White and Zlotnicka Spotted fatteners. Anim. Sci. Pap. Rep. 27:115-125.

Honikel, K. O. 1998. Reference methods for the assessment of physical characteristics of meat. Meat Sci. 49:447-457.

Jankowiak, H., M. Bocian, W. Kapelanski, and A. Roslewska. 2010. The relationship between carcass fatness and intramuscular fat content, and fatty acids profile in pig meat. Zywn-Nauk. Technol. Ja. 17:199-208.

Jankowiak, H., W. Kapelanski, B. E. Kwiatkowska, M. Biegniewska, and A. Cebulska. 2009. Carcass and meat quality of Zlotnicka Spotted pigs in comparison to Polish Large White $\times$ Polish Landrace crossbred pigs. Res. Pig Breed 3:4-6.

Kapelanski, W., J. T. Buczynski, and M. Bocian. 2006. Slaughter value and meat quality in the Polish native Zlotnicka Spotted pig. Anim. Sci. Pap. Rep. 24:7-13.
Kelly, H. R. C., H. M. Browning, J. E. L. Dav, A. Martins, G. P. Pearce, C. Stopes, and S. A. Edwards. 2007. Effect of breed type, housing and feeding system on performance of growing pigs managed under organic conditions. J. Sci. Food Agric. 87:2794-2800

Klusáček, J., T. Diblík, V. Svoboda, and V. Domabyl. 1991. Production potential of the Prestice Black-Pied and improved Prestice Black-Pied pigs (in Czech). Ziv. Vyr. 36:649-650.

Kolář, M. and J. Pavlík. 1989. Possibilities of improving the production traits of the pigs of the Prestice Black Pied breed through hybrid sows (in Czech). Ziv. Vyr. 34:47-54.

Krieter, J. and E. Tholen. 2001. Selection for meat quality within pure bred lines in swine - a study. Arch. Tierz. 44:531-546.

Nurnberg, K., D. Dannenberger, G. Nuernberg, and T. Paulke. 2013. Fat quality of heavy German Saddleback pigs. Fleischwirtschaft 93:118-122.

Nurnberg, K., G. Kuhn, K. Ender, G. Nurnberg, and M. Hartung. 1997. Characteristics of carcass composition, fat metabolism and meat quality of genetically different pigs. Eur. J. Lipid Sci. Technol. 99:443-446.

Oravcová, M., J. Huba, L. Hetenyi, J. Bulla, V. Mátlová, and O. Kadlečík. 2004. Farm animal genetic resources in the Slovak Republic. Czech J. Anim. Sci. 49:430-435.

Pulkrábek, J., T. Adamec, J. Wolf, J. Fiedler, V. Jakubec, L. Houška, and F. Štefunka. 1993. Possibilities of determining the portion of lean meat in the sides of pork (in Czech). Ziv. Vyr. 38:269-276

Rauw, W. M., E. Kanis, E. N. Noordhuizen-Stassen., and F. J. Grommers. 1998. Undesirable side effects of selection for high production efficiency in farm animals: A review. Livest. Prod. Sci. 56:15-33.

Ruusunen, M., E. Puolanne, M. L. Sevon-Aimonen, K. Partanen, L. Voutila, and J. Niemi. 2012. Carcass and meat quality traits of four different pig crosses. Meat Sci. 90:543-547.

Serrano, M. P., D. G. Valencia, M. Nieto, R. Lazaro, and G. G. Mateos. 2008. Influence of sex and terminal sire line on performance and carcass and meat quality of Iberian pigs reared under intensive production systems. Meat Sci. 78:420428

Szulc, K., K. Borzuta, D. Lisiak, J. T. Buczynski, J. Strzelecki, E. Grzeskowiak, F. Magda, and B. Lisiak. 2011. Influence of cross-breeding of native breed sows of Zlotnicka Spotted with boars of Duroc and Polish Large White (PLW) breeds on the slaughter value fatteners. Afr. J. Biotechnol. 10:16402-16405.

Szulc, K., E. Skrzypczak, J. T. Buczynski, D. Stanislawski, A. Jankowska-Makosa, and D. Knecht. 2012. Evaluation of fattening and slaughter performance and determination of meat quality in Zlotnicka Spotted pigs and their crosses with the Duroc breed. Czech J. Anim. Sci. 57:95-107. 